\title{
Growth inhibitory effects of pegylated IFN- $\alpha 2 b$ and 5-fluorouracil in combination on renal cell carcinoma cell lines in vitro and in vivo
}

\author{
FUKUKO MORIYA ${ }^{1-3}$, SACHIKO OGASAWARA ${ }^{1,3}$, YUJI BASAKI ${ }^{4}$, JUN AKIBA ${ }^{1,3}$, SAKIKO KOJIRO $^{1,3}$, \\ SUGURU FUKAHORI ${ }^{1,3}$, HIRONORI ISHIZAKI ${ }^{1-3}$, NAOYO NISHIDA ${ }^{1,3}$, KEI MATSUOKA ${ }^{2,3}$, \\ MASAMICHI KOJIRO ${ }^{1,3}$, MICHIHIKO KUWANO ${ }^{3,4}$ and HIROHISA YANO ${ }^{1,3}$ \\ Departments of ${ }^{1}$ Pathology and ${ }^{2}$ Urology, Kurume University School of Medicine, ${ }^{3}$ Research Center of \\ Innovative Cancer Therapy of the 21st Century COE Program for Medical Science, Kurume University, \\ 67 Asahi-machi, Kurume, Fukuoka 830-0011; ${ }^{4}$ Station-II for Collaborative Research Center, \\ Kyushu University, 3-1-1 Maidashi, Higashi-ku, Fukuoka, Fukuoka 812-8582, Japan
}

Received May 16, 2008; Accepted July 18, 2008

DOI: 10.3892/ijo_00000050

\begin{abstract}
We investigated the effects of pegylated IFN- $\alpha 2 b$ (PEG-IFN- $\alpha 2 b$ ) alone and PEG-IFN- $\alpha 2 b$ plus 5-fluorouracil (5-FU) in vitro on the proliferation of renal cell carcinoma (RCC) cell lines. After the transplantation of RCC cells into nude mice, we administered IFN (PEG-IFN- $\alpha 2 b$ or IFN- $\alpha 2 b$ ) alone, 5-FU alone, or IFN (PEG-IFN- $\alpha 2 b$ or IFN- $\alpha 2 b$ ) plus 5-FU; and investigated tumor volume, tumor weight, the numbers of apoptotic cells and artery-like blood vessels, relative mRNA expression levels of enzymes which relate to 5-FU metabolism, angiogenesis factor, and type I interferon receptor. RCC cells in vitro were generally and relatively resistant to the anti-proliferative effects of PEG-IFN- $\alpha 2 b$, but the addition of 5-FU augmented IFN-induced anti-proliferative effects with the induction of apoptosis. PEG-IFN- $\alpha 2 b$ in vivo presented stronger anti-tumor effects than IFN- $\alpha 2 b$, and its combination with 5-FU augmented the effects. The significant anti-tumor effect of the combination treatment was the increase in apoptotic cell number, but there were no significant differences in the suppression of angiogenesis, expression of IFN receptor, and the actions of metabolic enzymes of 5-FU. In conclusion, PEG-IFN- $\alpha 2 \mathrm{~b}$ presents stronger anti-tumor effects than non-pegylated IFN, and the effects are augmented in the combination with 5-FU. Our findings suggest the clinical usefulness of PEG-IFN- $\alpha 2 b$ in the treatment of RCC.
\end{abstract}

Correspondence to: Dr F. Moriya, Department of Pathology, Kurume University School of Medicine, 67 Asahi-machi, Kurume, Fukuoka 830-0011, Japan

E-mail: moriya_fukuko@kurume-u.ac.jp

Key words: renal cell carcinoma, pegylated interferon- $\alpha 2 \mathrm{~b}$, 5-fluorouracil, combination therapy, apoptosis

\section{Introduction}

Renal cell carcinoma (RCC) is highly resistant to conventional chemotherapy. The objective response rate is $6-9 \%$ for vinblastine and $5-8 \%$ for 5-fluorouracil (5-FU) (1). The response rates of treatment regimens using interleukin- 2 are 6-31\% (2), and the therapeutic response rates of interferon (IFN)- $\alpha$ are $4-33 \%$ in patients with metastatic RCC (3). The response rates of immunochemical therapies that utilize chemotherapeutic agents with IFN- $\alpha$ or interleukin- 2 range between 8 and 39\% (4). Immunochemical therapy is the best treatment for advanced RCC, but potential synergetic effects of the medicines as well as their mechanisms remain to be elucidated.

Wadler and Wienik (5) for the first time proposed a combination therapy of IFN- $\alpha$ and 5-FU in 1988 in their study using colon cancer cell lines. Later, this combination therapy was applied to various types of human malignancies including RCC and hepatocellular carcinoma (HCC). 5-FU has two major anti-tumor mechanisms: one involves its active metabolite 5-fluoro-2'-deoxyuridine-5'-monophosphate (FdUMP), inhibiting the activity of thymidylate synthase (TS) and consequently DNA synthesis; the other is related to the incorporation of 5-FU metabolite into RNA and DNA, thereby disrupting normal RNA processing and function. The sensitivity of cancer cells to 5-FU is often influenced by the enzymes affecting 5-FU metabolism, including TS, dihydropyrimidine dehydrogenase (DPD), orotate phosphoribosyl transferase (OPRT), thymidine phosphorylase (TP), uridine phosphorylase (UP) and thymidine kinase (TK).

PEG-IFN- $\alpha 2 b$, a new interferon, is a covalent conjugate of recombinant IFN- $\alpha 2 b$ with monomethoxy polyethylene glycol (PEG) in a 1:1 molar ratio that produces a $31,000-\mathrm{Da}$ molecule (6). PEG conjugation increases the size of the molecule, therefore, the absorption of the pegylated molecule is slower, its serum half-life is longer, and its rate of clearance from the plasma is lower than that of the unmodified molecule. PEG-IFN- $\alpha 2 b$ thereby increases patient exposure 
to IFN- $\alpha 2 b$ and requires less frequent administration (6). Clinical trials in chronic hepatitis $\mathrm{C}$ patients have suggested that PEG-IFN- $\alpha$ preparations produce more potent therapeutic effects than IFN- $\alpha$ preparations (6-10). Yano et al (11) examined the in vitro and in vivo anti-tumor effects of PEG- and non-PEG-IFN- $\alpha 2 b$ on human liver cancer cells, and they reported that the anti-tumor effect of PEG-IFN- $\alpha 2 b$ was significantly more potent than that of non-PEG-IFN- $\alpha 2 b$. In addition, Motzer et al (12) conducted a phase I study of PEG-IFN- $\alpha 2 b$ on advanced renal cancer patients, and reported that partial response was obtained in 5 (19\%) patients. Yet, there have been few basic studies evaluating the efficacy of PEG-IFN- $\alpha 2 b$ on RCC in vitro and in vivo.

Our current study examined the in vitro and in vivo antitumor effects of PEG-IFN- $\alpha$, IFN- $\alpha 2 b, 5-F U$, and the combination of one of the two IFNs and 5-FU, on RCC cell lines, using PEG-IFN- $\alpha 2 b$ concentrations close to the clinical dosage. We also examined the effects of the therapies on apoptotic cells, artery-like blood vessels, the enzymes affecting 5-FU metabolism, vascular endothelial growth factor (VEGF), and type I IFN receptor subunits in human $\mathrm{RCC}$ tumors which were developed in nude mice.

\section{Materials and methods}

Cell lines and cell culture. This study used 8 human RCC cell lines. KRC/Y (13) was established in our laboratory. KUR11 and KURM were donated by Professor K. Itoh of the Department of Immunology at our University. Caki-1, Caki-2, and ACHN were purchased from American Type Culture Collection. VMRC-RCW was purchased from Japan Health Sciences Foundation. OS-RC-2 was purchased from Riken Cell Bank (Tsukuba, Japan).

Culture medium for KRC/Y consisted of Dulbecco's modified Eagle's medium (Nissui Seiyaku Co., Tokyo, Japan) supplemented with heat-inactivated $\left(56^{\circ} \mathrm{C}, 30 \mathrm{~min}\right) 5 \%$ fetal bovine serum (FBS, Bioserum, Vic, Australia), $100 \mathrm{U} / \mathrm{ml}$ penicillin and $100 \mu \mathrm{g} / \mathrm{ml}$ streptomycin (Gibco BRL/Life Technologies Inc., Gaithersburg, MD). Culture medium for Caki-1, Caki-2, VMRC-RCW and ACHN consisted of modified Eagle's medium (Gibco); the medium for KUR11, KURM and OS-RC-2 consisted of RPMI-1640; and each medium was supplemented with $10 \%$ FBS, $100 \mathrm{U} / \mathrm{ml}$ penicillin and $100 \mu \mathrm{g} / \mathrm{ml}$ streptomycin. Cells were cultured in an atmosphere of $5 \% \mathrm{CO}_{2}$ in air at $37^{\circ} \mathrm{C}$. 5-FU was purchased from Kyowa Hakko K.K. (Tokyo, Japan).

IFN and reagents. PEG-IFN- $\alpha 2 \mathrm{~b}$ (PEG Intron $\left.{ }^{\circledR}\right)$ and IFN- $\alpha 2 b$ (Intron ${ }^{\circledR}$ A) were provided by Schering-Plough K.K. (Osaka, Japan). The specific activity of PEG-IFN- $\alpha 2$ b was $6.4 \times 10^{7} \mathrm{IU} / \mathrm{mg}$ protein and that of IFN- $\alpha 2 \mathrm{~b}$ was $2.6 \times 10^{8} \mathrm{IU} /$ $\mathrm{mg}$ protein.

Rat antibody against mouse endothelial cells (anti-CD34, clone MEC14.7) was purchased from Serotec Co., Oxford, UK; and mouse monoclonal antibody against human $\alpha$-smooth muscle actin (SMA) that cross-reacts with mouse $\alpha$-SMA (clone 1A4), from Immunon (Pittsburgh, PA).

Effects of PEG-IFN- $\alpha 2 b$ on the proliferation of RCC cell lines in vitro. The effects of PEG-IFN- $\alpha 2 b$ or $5-\mathrm{FU}$ on cell proliferation were examined in colorimetric assays by using 3-(4,5-dimethylthiazol-2yl-yl-)-2,5-diphenyl tetrazolium bromide (MTT) cell growth assay kits (Chemicon International Inc.) as described elsewhere (14). Briefly, the RCC cells (1.5-5x $10^{3}$ cells per well) were seeded on 96-well plates (Nunc Inc., Roskilde, Denmark), cultured for $24 \mathrm{~h}$, and the culture medium was changed to a new medium with or without PEG-IFN- $\alpha 2 b(8,32,128,512$ or $2,048 \mathrm{IU} / \mathrm{ml})$. After culturing for $24,48,72$ or $96 \mathrm{~h}$, the number of viable cells was measured with ImmunoMini NJ-2300 (Nalge Nunc International, Tokyo, Japan) by setting the test wavelength to $570 \mathrm{~nm}$ and the reference wavelength to $630 \mathrm{~nm}$. To keep the optical density within linear range, all experiments were performed when the cells were in the logarithmic growth phase. The effects of IFN- $\alpha 2 b$ on the growth of VMRC-RCW cells were also examined in the same manner.

Effects of combination therapy of PEG-IFN- $\alpha 2 b$ and 5-FU on the proliferation of RCC cell lines in vitro. RCC cells (VMRCRCW, 3,000 cells/well) were seeded on 96-well plates (Nunc Inc.), cultured for $24 \mathrm{~h}$, and then the culture medium was changed to a new medium containing PEG-IFN- $\alpha 2 \mathrm{~b}$ alone $(0$, $160,317,625,1,250,2,500,5,000$ or $10,000 \mathrm{IU} / \mathrm{ml}) ; 5-\mathrm{FU}$ alone $(0,0.6,1.25,2.5,5$ or $10 \mu \mathrm{M})$; or both 5 -FU $(0,0.6$, $1.25,2.5,5,10 \mu \mathrm{M})$ and PEG-IFN- $\alpha 2 \mathrm{~b}(0,160,317,625$, $1,250,2,500,5,000$ or $10,000 \mathrm{IU} / \mathrm{ml})$. After $96 \mathrm{~h}$ of culture, the number of viable cells was examined by MTT assay as described above.

The synergy of cooperative cytotoxicity was determined by the median-effect principle as described by Chou and Talalay (15). Data from each sample were analyzed by using CalcuSyn ver. 2 (Biosoft, Cambridge, UK).

Morphological observation. For morphological observation by light microscopy, 8 RCC cell lines were seeded on LabTek tissue culture chamber slides (Nunc Inc.), cultured with or without PEG-IFN- $\alpha 2 \mathrm{~b}(1,024,4,098$ or $8,192 \mathrm{IU} / \mathrm{ml})$ for $72 \mathrm{~h}$, fixed for $30 \mathrm{~min}$ in Carnoy's solution, and stained with hematoxylin and eosin (H\&E).

In another experiment, one RCC cell line (VMRC-RCW, 8,000 cells/chamber) was seeded on Lab-Tek tissue culture chamber slides (Nunc Inc.), cultured with PEG-IFN- $\alpha 2 b$ alone $(0,160,317,625,1,250,2,500,5,000 \mathrm{IU} / \mathrm{ml}) ; 5-\mathrm{FU}$ alone $(0,0.6,1.25,2.5,5.0 \mu \mathrm{M})$; PEG-IFN- $\alpha 2 \mathrm{~b}(0,160,317$, $625,1,250,2,500,5,000 \mathrm{IU} / \mathrm{ml})$ plus 5 -FU $(0,0.6,1.25,2.5$, $5.0 \mu \mathrm{M}$ ), or PBS, for $72 \mathrm{~h}$, fixed for $30 \mathrm{~min}$ in Carnoy's solution and $\mathrm{H} \& \mathrm{E}$ stained.

Effects of PEG-IFN- $\alpha 2 b$ and IFN- $\alpha 2 b$ on RCC cell proliferation in nude mice. Cultured VMRC-RCW cells $\left(1.0 \times 10^{7}\right.$ cells/ mouse) were subcutaneously (s.c.) injected into the backs of 4-week-old female BALB/c athymic nude mice $(n=62)$ (Clea Japan, Inc, Osaka, Japan). One week later when the largest diameter of the tumor reached $\sim 10 \mathrm{~mm}$ (day 0 ), the mice were divided into 7 groups ( $n=8$ or 9 each) in a manner to equalize the mean tumor diameter of each group. Each mouse received a subcutaneous injection of $0.1 \mathrm{ml}$ of medium alone (control group), medium containing $640,6,400,64,000$ or $640,000 \mathrm{IU}$ of PEG-IFN- $\alpha 2 b$, or medium containing 640 or $6,400 \mathrm{IU}$ of IFN- $\alpha 2 \mathrm{~b}$, twice a week for 2 consecutive weeks (on day 1, 4, 
A

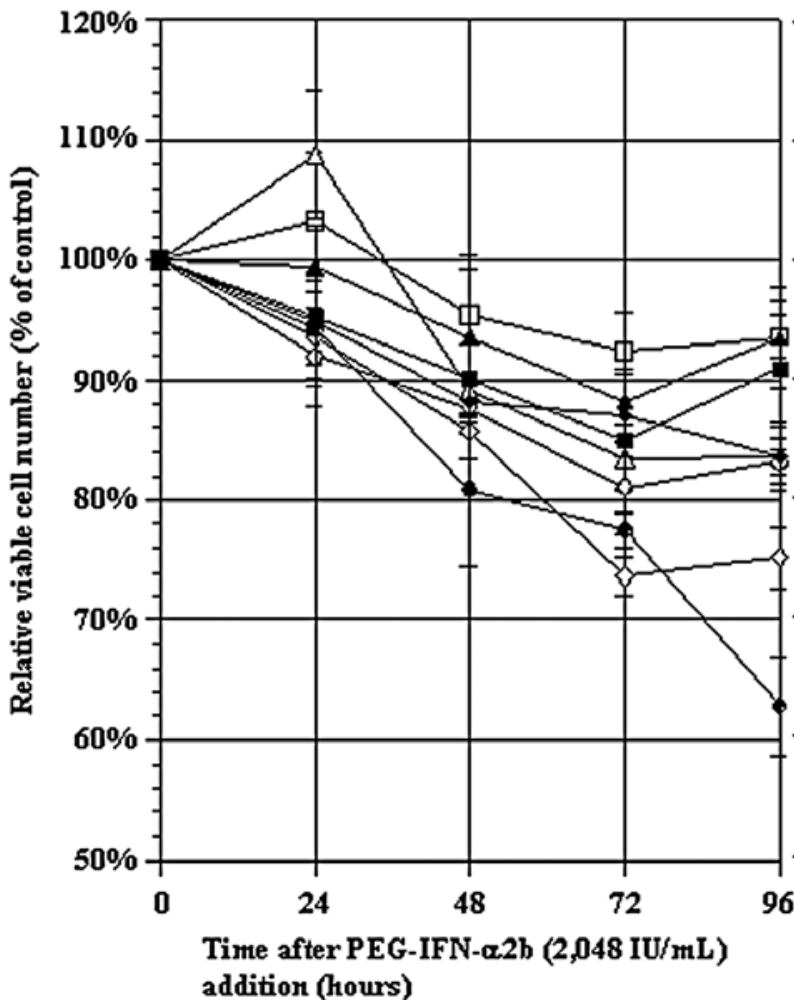

B

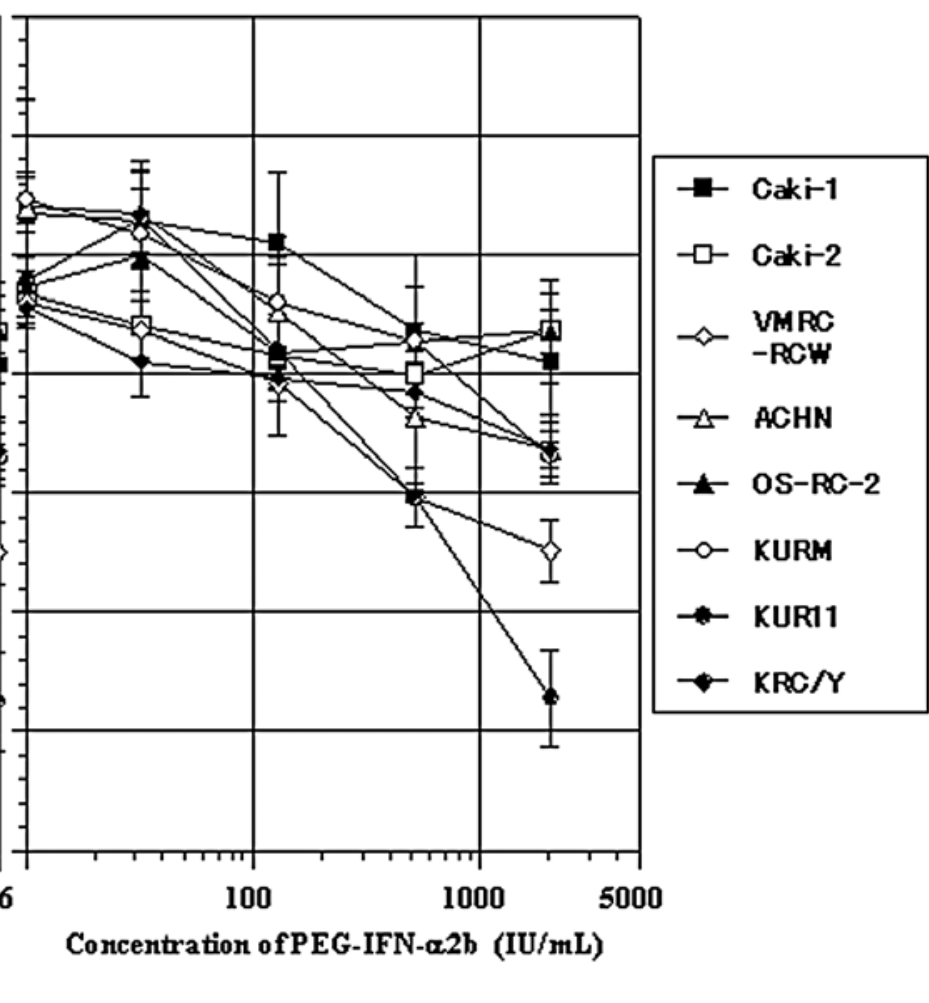

Figure 1. Anti-proliferative effects of PEG-IFN- $\alpha 2$ b. (A) Chronological changes in relative viable cell number (\% of the control) after adding $2,048 \mathrm{IU} / \mathrm{ml}$ of PEG-IFN- $\alpha 2 \mathrm{~b}$. Growth was significantly suppressed over time in 2 cell lines (KUR11 and KRC/Y). (B) Ninety-six hours after adding 8, 32, 128, 512 or $2,048 \mathrm{IU} / \mathrm{ml}$ of PEG-IFN- $\alpha 2$ b. Cell proliferation was suppressed in a dose-dependent manner in 6 cell lines (all but Caki-2 and OS-RC-2). Eight samples were used in each experiment. The experiment was repeated at least three times for each cell line. The values represent the average \pm SE.

8 and 11). The clinical daily dose of IFN- $\alpha 2 b$ for human $\mathrm{RCC}$ is $600 \times 10^{4} \mathrm{IU} /$ body $\left(1.2 \times 10^{5} \mathrm{IU} / \mathrm{kg}\right)$, and this is approximately four times the lowest dose $\left(3.2 \times 10^{4} \mathrm{IU} / \mathrm{kg}\right)$ used in this experiment. Tumor size was measured in two directions by using calipers on the first and second days of s.c. injection (day 1 and 2) and then once every 2 days until day 14, and tumor volume $\left(\mathrm{mm}^{3}\right)$ was estimated by using the equation: Length $\mathrm{x}(\text { Width })^{2} \times 0.5$. Mouse body weight was measured on day 0,8 and 14 . On day 15 , all mice were sacrificed and the tumors were removed.

The animals received human care according to criteria outlined in the 'Guide for the Care and Use of Laboratory Animals' prepared by the National Academy of Sciences and published by the National Institutes of Health (NIH publication 86-23, revised 1985).

Effects of combination therapy of PEG-IFN- $\alpha 2 b$ and 5-FU on RCC cell proliferation in nude mice. VMRC-RCW cells ( $7.5 \times 10^{6}$ cells/mouse) were subcutaneously injected into 4week-old female BALB/c athymic nude mice $(n=58)$. The mice were divided into 7 groups ( $\mathrm{n}=8$ or 9 each) on day 7 when tumor size reached $\sim 10 \mathrm{~mm}$ in diameter, and each group was assigned to one of the 7 treatments: i) PEG-IFN$\alpha 2 b$ alone $(6,400 \mathrm{IU})$; ii) IFN- $\alpha 2 \mathrm{~b}$ alone $(6,400 \mathrm{IU})$; iii) low dose 5-FU alone (160 $\mu \mathrm{g})$; iv) high dose 5-FU alone (320 $\mu \mathrm{g})$; v) combination therapy of PEG-IFN- $\alpha 2 b(6,400 \mathrm{IU})$ and low dose 5-FU; vi) combination therapy of IFN- $\alpha 2 b$ (6,400 IU) and low dose 5-FU; and (vii) control.

5-FU was administered intra-abdominally every day for 2 consecutive weeks. The dose of 5-FU $(160 \mu \mathrm{g} / \mathrm{mouse}, 8 \mathrm{mg} /$ $\mathrm{kg}$ ) is comparable to the clinical dose.

Tumor size measurement and IFN administration were performed in the same manner as described above. On day 15 , all mice were sacrificed and each tumor was removed. After the tumor weight was measured, half of the obtained tumors were used for histological examination and the other half were used for quantitative real-time RT-PCR.

The number of cells showing characteristics of apoptosis such as cytoplasmic shrinkage, chromatin condensation and nuclear fragmentation was counted in ten $0.25 \mathrm{~mm}^{2}$ areas within an H\&E-stained specimen, and the average number per area was obtained. The TUNEL technique (ApopTag ${ }^{\circledR}$ Peroxidase In Situ Apoptosis Detection Kits, Chemicon International, CA, USA) was also used to detect apoptotic cells. The average number of TUNEL-positive cells per area was obtained as described above.

Immunohistochemistry. Double immunohistochemical staining was performed by using anti-mouse endothelial cell (antiCD34) antibody, anti-human $\alpha$ smooth muscle actin ( $\alpha$-SMA) antibody and histofine simple stain mouse Max-Po (Rat) kits (Nichirei, Tokyo, Japan) as described elsewhere (16). We 


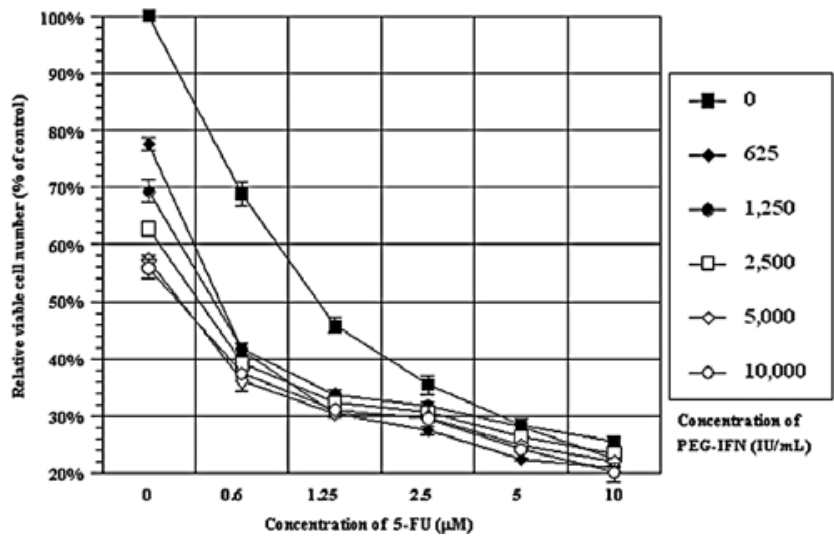

Figure 2. Anti-proliferative effects of the combination therapy of PEG-IFN$\alpha 2 \mathrm{~b}$ and 5-FU on VMRC-RCW cells in a 96-h culture. The relative viable cell number decreased dose-dependently. Two samples were used in each experiment. The experiment was repeated three times. The values represent the average \pm SE. PEG-IFN, PEG-IFN- $\alpha 2 b$.

calculated the number of artery-like blood vessels in the entire area of each section and obtained for each the mean number per $\mathrm{mm}^{2}$.

cDNA preparation and quantitative real-time $R T-P C R$. Total RNA was extracted using RNA-Bee ${ }^{\mathrm{TM}}$ (Tel-Test, Inc., TX) and reverse transcribed using Superscript ${ }^{\mathrm{TM}}$ III First-Strand Synthesis System for RT-PCR (Invitrogen, CA) according to the manufacturer's instructions. Quantitative real-time RTPCR was performed with an ABI PRISM 7300 (Applied Biosystems, Foster City, CA). We examined 6 enzymes related to 5-FU metabolism, i.e., TS, TP, DPD, OPRT, UP and
TK. The sequences of the primers and probes for the 6 enzymes are listed elsewhere (17). The sequences for VEGF were 5'-CCATGAACTTTCTGCTGTCTTGG-3' as the forward primer, 5'-CTGCGCTGATAGACATCCATGA-3' as the reverse primer, and 5'-TGCTCTACCTCCACCATGC CAAGT-3' as the probe. The sequences of the primers and probes for VEGFR-1, IFNAR-1, IFNAR-2 and glyceraldehyde-3-phosphate dehydrogenase (GAPDH) were purchased from Applied Biosystems.

Statistical analysis. We used two-factorial ANOVA for the comparisons of tumor volume, tumor weight, number of apoptotic cells, number of artery-like blood vessels, and relative levels of mRNAs related to 5-FU metabolism.

\section{Results}

Effects of PEG-IFN- $\alpha 2 b$ on the proliferation of RCC cell lines in vitro. After adding 2,048 IU/ml of PEG-IFN- $\alpha 2 b$, the relative viable cell number of the cultured 8 cell lines was suppressed in a time-dependent manner until $72 \mathrm{~h}$, but at $96 \mathrm{~h}$, suppression was noted in only 2 cell lines (KRC/Y and KUR11). On the other hand, with different doses of PEG-IFN$\alpha 2 \mathrm{~b}$, the relative viable cell number at $96 \mathrm{~h}$ was suppressed in the 6 cell lines, i.e., VMRC-RCW, KRC/Y, KURM, KUR11, $\mathrm{ACHN}$ and Caki-1. In the 8 cell lines, $\mathrm{IC}_{50}$ was not reached for either time- and dose-dependent suppressions, but the most sensitive case was KUR11 with the dose of $2,048 \mathrm{IU} / \mathrm{ml}$ at $96 \mathrm{~h}$, i.e., the relative viable cell number was $62.7 \%$ of the control (Fig. 1).

In the VMRC-RCW cell line, the anti-tumor effects of PEG-IFN- $\alpha 2 b$ and IFN- $\alpha 2 b$ were not markedly different.
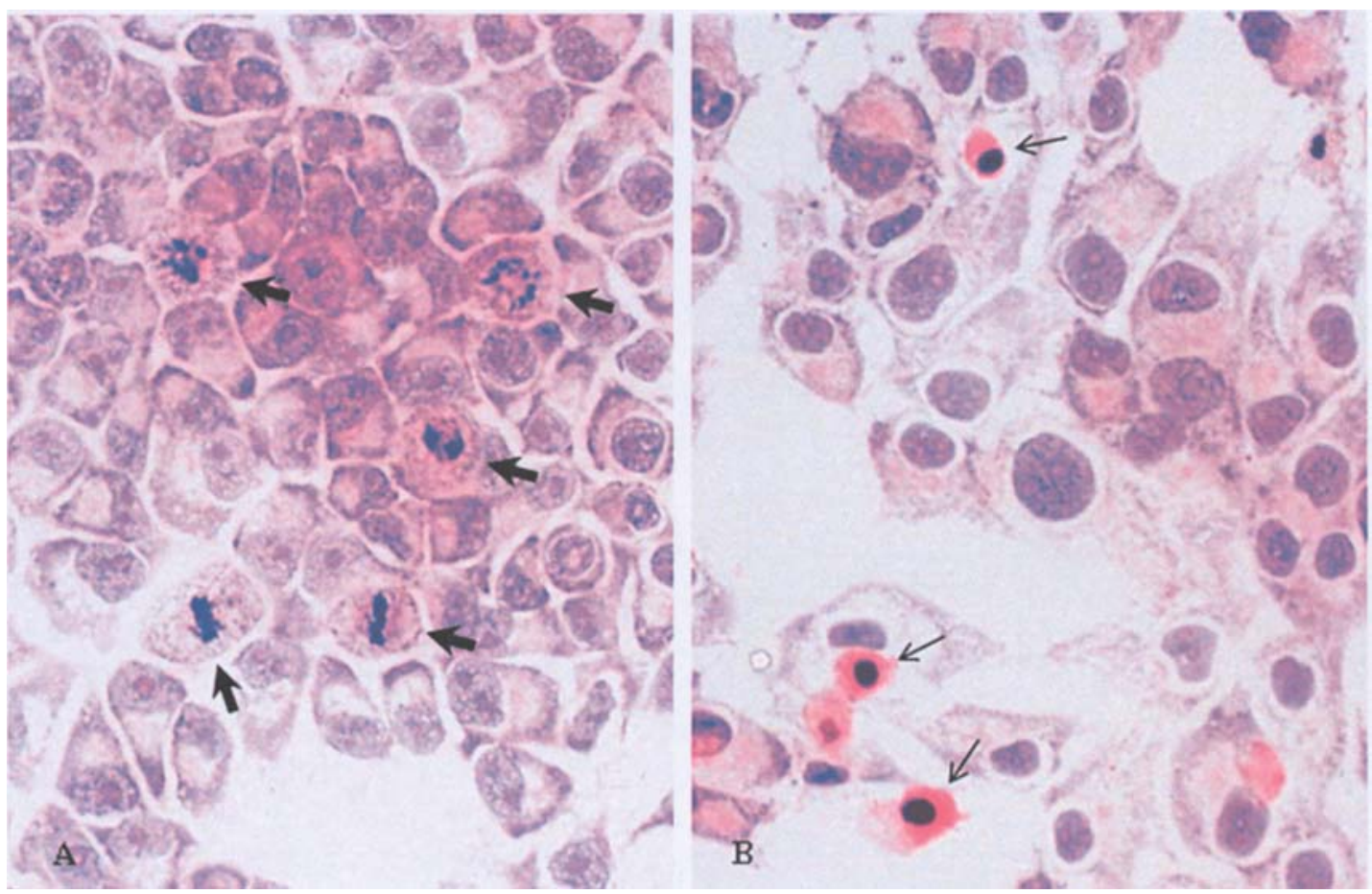

Figure 3. Photomicrograph of VMRC-RCW cells cultured for $72 \mathrm{~h}$ on a Lab-Tek Chamber Slide. (A) Without PEG-IFN- $\alpha 2 \mathrm{~b}$ in culture medium. Mitotic figures (thick arrows) were noted. (B) With 2,500 IU/m of PEG-IFN- $\alpha 2 \mathrm{~b}$ and $2.5 \mu \mathrm{M}$ of 5-FU in culture medium. Apoptotic cells (thin arrows) characterized by cytoplasmic shrinkage and chromatic condensation were noted (H\&E staining, $\mathrm{x} 200)$. 
Table I. Effects of PEG-IFN- $\alpha 2 b$ and IFN- $\alpha 2 b$ on RCC cell proliferation in nude mice.

\begin{tabular}{lccc}
\hline Treatment group & Number & $\begin{array}{c}\text { Tumor weight } \\
(\mathrm{g}, \text { mean } \pm \text { SE) }\end{array}$ & $\begin{array}{c}\text { Body weight } \\
(\mathrm{g}, \text { mean } \pm \text { SE on day 15) }\end{array}$ \\
\hline Control (culture medium) & 9 & $1.835 \pm 0.132$ & $17.122 \pm 0.362$ \\
IFN- $\alpha 2 \mathrm{~b}(640 \mathrm{IU})$ & 9 & $1.735 \pm 0.177$ & $16.089 \pm 0.599$ \\
IFN- $\alpha 2 \mathrm{~b}(6,400 \mathrm{IU})$ & 9 & $1.455 \pm 0.140$ & $16.667 \pm 0.420$ \\
PEG-IFN- $\alpha 2 \mathrm{~b}(640 \mathrm{IU})$ & 9 & $1.267 \pm 0.072^{\mathrm{a}, \mathrm{c}}$ & $16.156 \pm 0.308$ \\
PEG-IFN- $\alpha 2 \mathrm{~b}(6,400 \mathrm{IU})$ & 9 & $1.160 \pm 0.075^{\mathrm{b}}$ & $15.244 \pm 0.313$ \\
PEG-IFN- $\alpha 2 \mathrm{~b}(64,000 \mathrm{IU})$ & 9 & $0.920 \pm 0.126^{\mathrm{b}}$ & $16.922 \pm 0.601$ \\
PEG-IFN- $\alpha 2 \mathrm{~b}(640,000 \mathrm{IU})$ & 8 & $0.444 \pm 0.077^{\mathrm{b}}$ & $17.638 \pm 0.717$ \\
\hline
\end{tabular}

Cultured VMRC-RCW cells were subcutaneously transplanted in each nude mouse (1.0x $10^{7} /$ mouse). Seven days later, when the largest diameter of the tumor reached $\sim 10 \mathrm{~mm}$, mice were treated twice per week with s.c. injection of PEG-IFN- $\alpha 2 \mathrm{~b}$, IFN- $\alpha 2 \mathrm{~b}$, or culture medium. All mice were sacrificed on day $15 .{ }^{\mathrm{a}} \mathrm{p}<0.01$ and ${ }^{\mathrm{b}} \mathrm{p}<0.001$ vs. control; ${ }^{\mathrm{c}} \mathrm{p}<0.05$ vs. the same concentration of IFN.

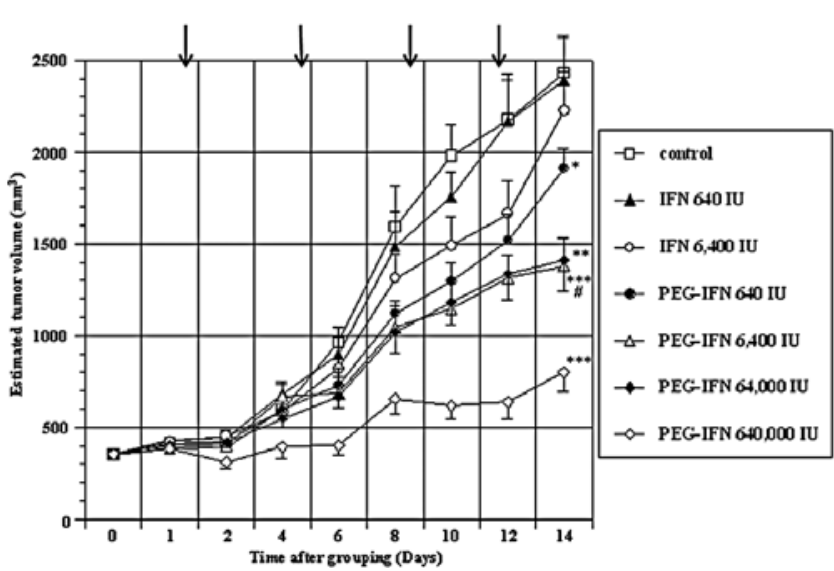

Figure 4. Chronological changes in the estimated volume of subcutaneously transplanted RCC tumors (VMRC-RCW cells, $1.0 \times 10^{7}$ ) in nude mice according to the treatment dose. Seven days after the transplantation, when the largest tumor diameter reached $\sim 10 \mathrm{~mm}$ (day 0 ), mice were divided into 7 groups ( $\mathrm{n}=8$ or 9 , each). The arrows show the days of treatment. ${ }^{*} \mathrm{p}<0.05$, ${ }^{* *} \mathrm{p}<0.01$ and ${ }^{* * *} \mathrm{p}<0.001$ vs. control; ${ }^{*} \mathrm{p}<0.01$ vs. the same dose of IFN- $\alpha 2 b$ $(6,400 \mathrm{IU})$. The values represent the average \pm SE. PEG-IFN, PEG-IFN- $\alpha 2 b$.

Effects of the combination treatment of PEG-IFN- $\alpha 2 b$ and 5-FU on the growth of the VMRC-RCW cell line in vitro. Without 5-FU, the relative viable cell number did not decrease to $50 \%$ or lower of the control even when the highest dose of PEG-lFN- $\alpha 2 \mathrm{~b}(5,000 \mathrm{IU} / \mathrm{ml})$ was added to the culture. When 5-FU $(0.6 \mu \mathrm{M})$ was used in combination, the relative viable cell number was suppressed to $41.6 \%$ even when PEG-IFN$\alpha 2 b$ was at the lowest dose $(625 \mathrm{IU} / \mathrm{ml}$, Fig. 2). The antiproliferative effect of these two agents was additive, not synergistic.

Morphological examination in vitro. The 8 cell lines presented such apoptotic features as cytoplasmic shrinkage and chromatin condensation in a varying degree and in a dosedependent manner at $72 \mathrm{~h}$ after adding PEG-IFN- $\alpha 2 \mathrm{~b}$. For the combination treatment of PEG-IFN- $\alpha 2 b$ and 5-FU, more apoptotic cells were observed than in the PEG-IFN- $\alpha 2 b$

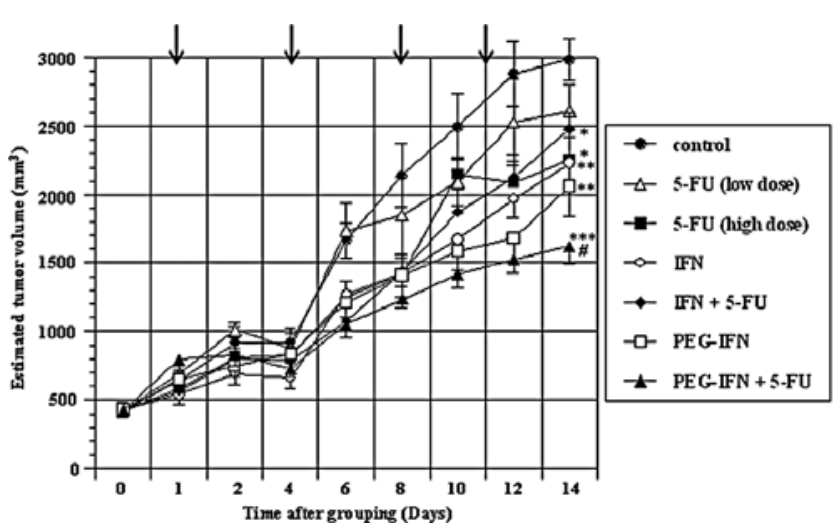

Figure 5. Chronological changes in the estimated volume of subcutaneously transplanted RCC tumors (VMRC-RCW cells, $7.5 \times 10^{6}$ ) in nude mice according to the treatment method. Seven days after the transplantation, when the largest tumor diameter reached $\sim 10 \mathrm{~mm}$ (day 0), mice were divided into 7 groups ( $\mathrm{n}=8$ or 9 , each), i.e., PEG-IFN- $\alpha 2 \mathrm{~b}(6,400 \mathrm{IU})$ alone; IFN- $\alpha 2 b(6,400$ IU) alone; combination of 5-FU and PEG-IFN- $\alpha 2 b(6,400$ IU) or IFN- $\alpha 2 \mathrm{~b}(6,400 \mathrm{IU}) ; 5-\mathrm{FU}$ alone (low or high dose); and culture medium alone (control). The arrows show the days of treatment. ${ }^{*} \mathrm{p}<0.05,{ }^{* *} \mathrm{p}<0.01$ and ${ }^{* * *} \mathrm{p}<0.001 \mathrm{vs}$. control; ${ }^{*} \mathrm{p}<0.001$ vs. IFN- $\alpha 2 \mathrm{~b}$ and $5-\mathrm{FU}$. The values represent the average \pm SE. PEG-IFN, PEG-IFN- $\alpha 2 b$.

alone-treated cells, and the apoptotic cells increased dosedependently to PEG-IFN- $\alpha 2$ b plus 5-FU (Fig. 3).

Effects of PEG-IFN- $\alpha 2 b$ on RCC cell proliferation in nude mice. Chronological changes in estimated tumor volume after IFN administration to nude mice are summarized in Fig. 4. Dose-dependent suppression of tumor volume was observed in mice receiving PEG-IFN- $\alpha 2 b$. The estimated tumor volume on day 14 in the mice receiving 6,400 IU of PEGIFN- $\alpha 2 b$ became $61.9 \%$ of the mice receiving the same dose of IFN- $\alpha 2 b(p<0.01)$ and $56.8 \%$ of the control $(p<0.001)$. The tumor weight on day 15 in the mice receiving $6,400 \mathrm{IU}$ of PEG-IFN- $\alpha 2 b$ became $63.2 \%$ of the control $(p<0.001$, Table I).

Significant differences in the estimated tumor volume were observed between each PEG-IFN- $\alpha 2$ b group (640, 6,400, 
Table II. Effects of combination therapy of PEG-IFN- $\alpha 2 b$ and 5-FU on RCC cell proliferation in nude mice.

\begin{tabular}{lccc}
\hline Treatment group & Number & $\begin{array}{c}\text { Tumor weight } \\
(\mathrm{g}, \text { mean } \pm \text { SE) }\end{array}$ & $\begin{array}{c}\text { Body weight } \\
(\mathrm{g}, \text { mean } \pm \text { SE on day 15) }\end{array}$ \\
\hline Control (culture medium) & 8 & $2.255 \pm 0.102$ & $17.188 \pm 0.578$ \\
5-FU (low dose) & 9 & $2.430 \pm 0.185$ & $16.778 \pm 0.595$ \\
5-FU (high dose) & 7 & $1.603 \pm 0.107^{\mathrm{c}}$ & $15.686 \pm 0.814$ \\
IFN- $\alpha 2 \mathrm{~b}$ alone & 8 & $1.812 \pm 0.084^{\mathrm{b}}$ & $16.363 \pm 0.692$ \\
IFN- $\alpha 2 \mathrm{~b}+5-\mathrm{FU}$ & 8 & $1.917 \pm 0.170$ & $16.344 \pm 0.426$ \\
PEG-IFN- $\alpha 2 \mathrm{~b}$ & 8 & $1.771 \pm 0.172^{\mathrm{a}}$ & $15.963 \pm 0.459$ \\
PEG-IFN- $\alpha 2 \mathrm{~b}+5-\mathrm{FU}$ & 9 & $1.742 \pm 0.194^{\mathrm{a}}$ & $15.767 \pm 0.621$ \\
\hline
\end{tabular}

Cultured VMRC-RCW cells were subcutaneously transplanted in each nude mouse $\left(7.5 \times 10^{6} /\right.$ mouse). Seven days later, when the largest diameter of the tumor reached $\sim 10 \mathrm{~mm}$, mice were treated with s.c. injection of IFNs and/or intraperitoneal injection of 5-fluorouracil (5-FU) daily. All mice were sacrificed on day 15 . The concentration of both PEG-IFN- $\alpha 2 b$ and IFN- $\alpha 2 b$ was $6,400 \mathrm{IU} / \mathrm{ml} .{ }^{\mathrm{a}} \mathrm{p}<0.05$, ${ }^{\mathrm{b}} \mathrm{p}<0.01$ and ${ }^{c} \mathrm{p}<0.001$ vs. control.

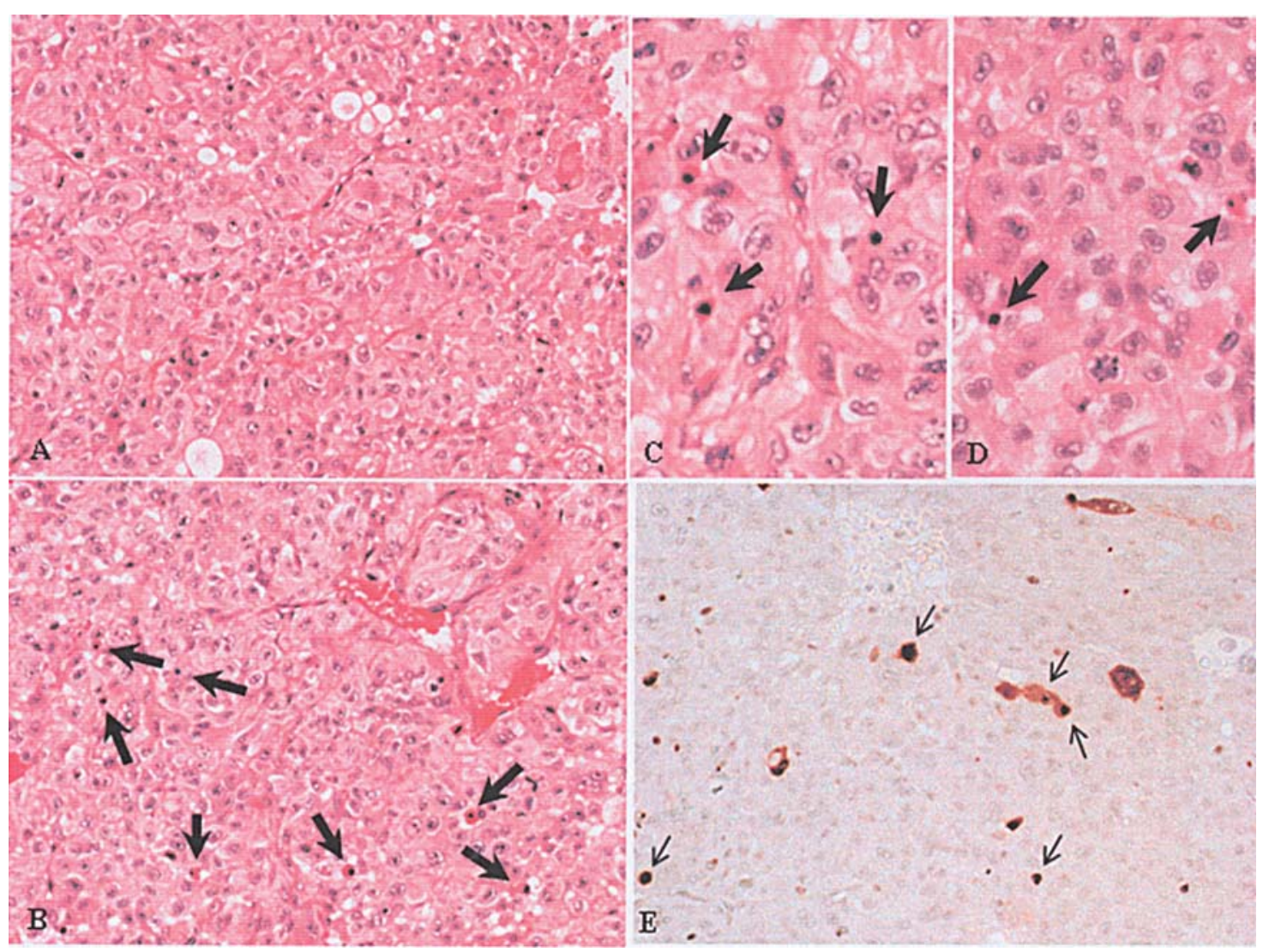

Figure 6. Photomicrograph of a subcutaneous human RCC tumor in nude mice, which developed after the injection of VMRC-RCW cells. (A) A control mouse that received culture medium alone. The tumor showed a thick trabecular arrangement of tumor cells and thin fibrous connective tissues and capillary vessels in the stroma. (B) A mouse that received PEG-IFN- $\alpha 2 b$ and 5-FU. There were many apoptotic tumor-cells (thick arrows, H\&E staining, $x 200$ ). (C and D) Higher magnifications of B (x400). Apoptotic tumor-cells characterized by shrinkage and eosinophilic change in the cytoplasm and chromatin condensation are shown (thick arrows, H\&E staining). (E) TUNEL-positive apoptotic cells showing brown nuclei (thin arrows, TUNEL staining, x200).

$64,000,640,000 \mathrm{IU})$ and the control $(\mathrm{p}<0.05$ to $\mathrm{p}<0.001$, Fig. 3). There was no significant difference between 640 or 6,400 IU of the IFN- $\alpha 2 b$ group and the control. There were no significant differences in body weight of the mice among the groups.
Effects of the combination therapy of PEG-IFN- $\alpha 2 b$ and $5-F U$ on RCC cell proliferation in nude mice. Chronological changes in estimated tumor volume are shown in Fig. 5. The tumor volume on day 14 for the combination therapy of PEG-IFN- $\alpha 2 b$ and 5-FU was 54.2\% of the control ( $p<0.0001)$. 
Table III. Relative mRNA expression levels of the enzymes related with 5-FU metabolism, VEGF, VEGFR-1 and type I IFN receptor subunits.

\begin{tabular}{lcrrrrrrrrr}
\hline Treatment group & DPD & TP & TK & TS & UP & OPRT & VEGF & VEGFR-1 & IFNAR-1 & IFNAR-2 \\
\hline 5-FU (low dose) & 129 & 101 & 68 & 182 & 59 & 48 & 116 & 135 & 122 & 94 \\
5-FU (high dose) & 72 & 50 & 52 & $40^{\mathrm{a}}$ & 86 & 41 & 30 & 93 & 59 & 90 \\
IFN- $\alpha 2 \mathrm{~b}$ & 110 & 71 & 82 & 119 & 100 & 103 & 97 & 134 & 108 & 174 \\
IFN- $\alpha 2 \mathrm{~b}+5$-FU & 95 & 80 & 85 & 74 & 53 & 106 & 56 & 111 & 63 & $44^{\mathrm{a}, \mathrm{d}}$ \\
PEG-IFN- $\alpha 2 \mathrm{~b}$ & $648^{\mathrm{b}, \mathrm{d}}$ & $420^{\mathrm{a}}$ & 313 & $297^{\mathrm{b}, \mathrm{d}}$ & 76 & 124 & $366^{\mathrm{a}, \mathrm{d}}$ & 277 & 159 & 217 \\
PEG-IFN- $\alpha 2 \mathrm{~b}+5-\mathrm{FU}$ & $159^{\mathrm{c}}$ & $143^{\mathrm{c}}$ & 162 & 129 & 129 & 86 & $251^{\mathrm{a}, \mathrm{e}}$ & 138 & 91 & 141 \\
\hline
\end{tabular}

mRNA levels were examined by quantitative real-time RT-PCR and normalized with GAPDH. The values of relative mRNA expression level represent the average of the ratio to the level of control in each group. ${ }^{a} \mathrm{p}<0.05$ and ${ }^{\mathrm{b}} \mathrm{p}<0.01 \mathrm{vs}$. control; ${ }^{\mathrm{c}} \mathrm{p}<0.05 \mathrm{vs}$. PEG-IFN- $\alpha 2 \mathrm{~b}$; ${ }^{\mathrm{d}} \mathrm{p}<0.05 \mathrm{vs}$. IFN- $\alpha 2 \mathrm{~b}$; and ${ }^{\mathrm{e}} \mathrm{p}<0.01 \mathrm{vs}$. IFN- $\alpha 2 \mathrm{~b}$ plus 5 -FU. DPD, dihydropyrimidine dehydrogenase; TP, thymidine phosphorylase; TK, thymidine kinase; TS, thymidylate synthase; UP, uridine phosphorylase; OPRT, orotate phosphoribosyl transferase; VEGF, vascular endothelial growth factor; VEGFR-1, VEGF receptor 1; IFNAR-1, type I interferon receptor subunit 1; and IFNAR-2, type I interferon receptor subunit 2 .

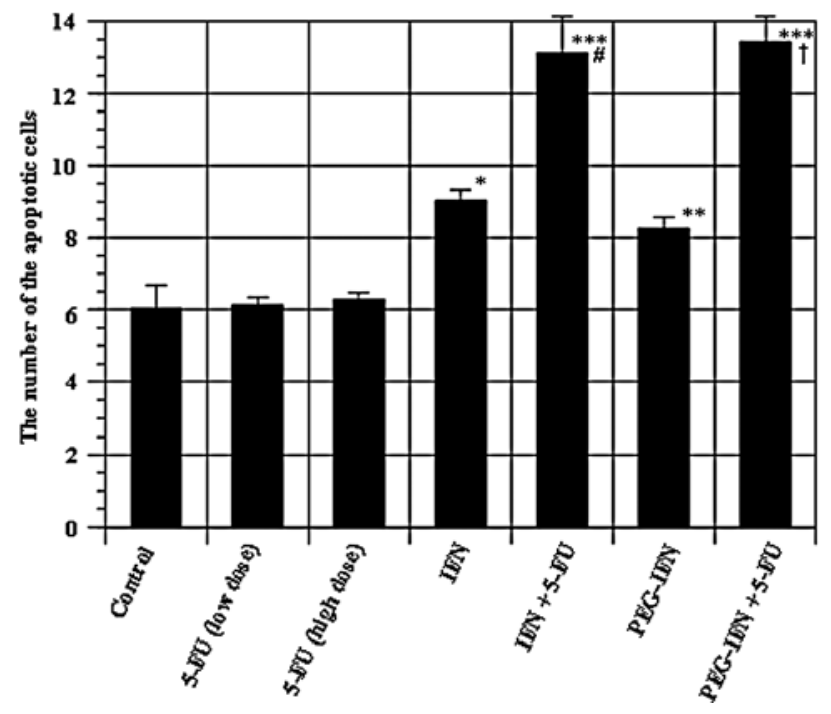

Figure 7. Number of apoptotic cells in the tumors. The number was counted in ten $0.25 \mathrm{~mm}^{2}$ areas in each section, and the average number per area in each group was obtained. ${ }^{*} \mathrm{p}<0.05,{ }^{* *} \mathrm{p}<0.01$ and ${ }^{* * *} \mathrm{p}<0.001$ vs. control; ${ }^{\#} \mathrm{p}<0.05$ vs. IFN- $\alpha 2 \mathrm{~b} ;{ }^{\dagger} \mathrm{p}<0.001$ vs PEG-IFN- $\alpha 2 \mathrm{~b}$. PEG-IFN, PEG-IFN- $\alpha 2 \mathrm{~b}$.

The tumor weights of the mice on day 15 were significantly different between the control and the 5-FU high dose group, each IFN alone group, and the combination group of PEGIFN- $\alpha 2 b$ and 5-FU. The two types of IFNs and/or 5-FU did not affect the body weight of the mice (Table II).

Histological examination of the RCC tumor specimens stained with $H \& E$ revealed that the number of apoptotic cells was significantly higher in the mice treated with $6,400 \mathrm{IU}$ of PEG-IFN- $\alpha 2 b(p<0.01)$ or 6,400 IU of IFN- $\alpha 2 b(p<0.05)$ in comparison to the control (Fig. 6A-D). The incidence of apoptosis in TUNEL-stained sections showed the same tendencies as those obtained in the H\&E-stained sections (Fig. 6E). The number of apoptotic cells significantly increased in the mouse tumors treated with the combination therapy in comparison to the control (for each IFN, p<0.0001). The number also significantly increased with the combination treatment of PEG-IFN- $\alpha 2 b$ and 5-FU in comparison to PEGIFN- $\alpha 2 b$ alone $(p<0.0001)$, and with the combination of IFN$\alpha 2 b$ and 5-FU in comparison to IFN- $\alpha 2 b$ alone $(p<0.05$, Fig. 7).

The results of quantitative real-time RT-PCR are shown in Table III. The VEGF mRNA levels increased significantly in the PEG-IFN- $\alpha 2 b$ alone group ( $p<0.05$ vs. control, $p<0.05$ vs. IFN- $\alpha 2 b$ ) and in the combination (PEG-IFN- $\alpha 2 b$ plus 5 -FU) group ( $\mathrm{p}<0.05$ vs. control, $\mathrm{p}<0.01$ vs. IFN- $\alpha 2 \mathrm{~b}$ plus 5 $\mathrm{FU})$. There were also significant increases in the expression levels of DPD $(\mathrm{p}<0.01)$, TP $(\mathrm{p}<0.05)$, and TS $(\mathrm{p}<0.05)$ in the PEG-IFN- $\alpha 2 b$ alone group in comparison to the control. On the other hand, significant decreases were observed in the expression levels of DPD $(\mathrm{p}<0.05)$ and TP $(\mathrm{p}<0.05)$ in the combination (PEG-IFN- $\alpha 2$ b plus 5-FU) group in comparison to the PEG-IFN- $\alpha 2 b$ alone group. In addition, the TS mRNA levels in the PEG-IFN- $\alpha 2 b$ group increased in comparison to the IFN- $\alpha 2 b$ group $(p<0.05)$. The relative mRNA levels of IFN- $\alpha 2 b$ receptors in the combination group were lower than the levels of the IFN alone group.

The number of artery-like blood vessels increased slightly in comparison to the control in the groups receiving IFN- $\alpha 2 b$ alone, PEG-IFN- $\alpha 2 b$ alone, or the combination therapies; and there were no significant differences among the 7 groups (Fig. 8).

\section{Discussion}

Shang et al (18) examined 5 RCC cell lines and reported that the greatest decrease in the viable cell number after adding $1,600 \mathrm{IU} / \mathrm{ml}$ of Sumiferon to the cultures was $42 \%$ (58\% of the control). On the other hand, Vyas et al (19) comparatively examined the anti-tumor effects of PEG-IFN- $\alpha 2 b$ and IFN$\alpha 2 b$ by using an RCC cell line, ACHN, and reported that the addition of $1,033 \mathrm{IU} / \mathrm{ml}$ of PEG-IFN- $\alpha 2 b$ suppressed the viable cell number to $50 \%$ of the control. Our current 


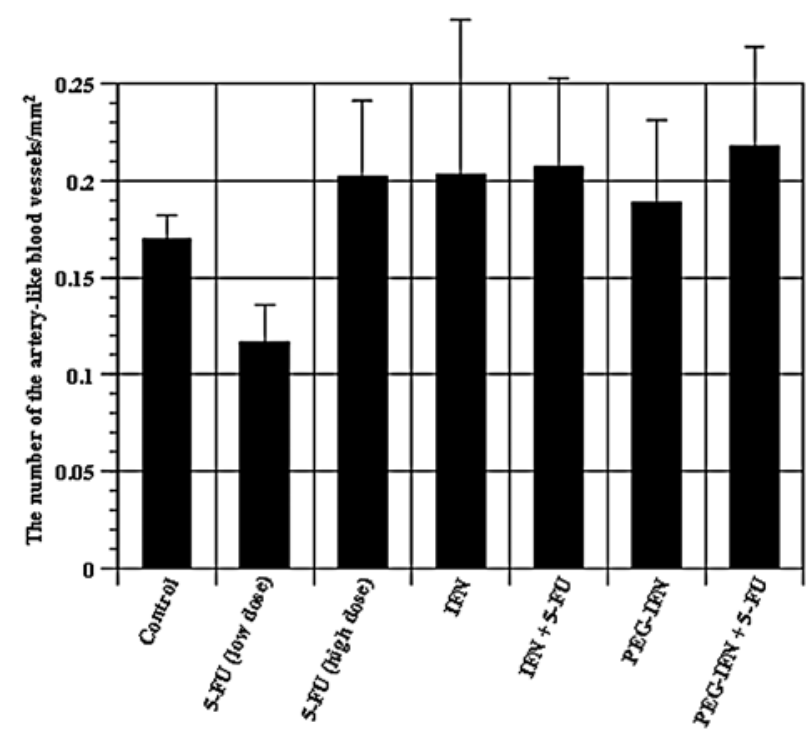

Figure 8 . Number of artery-like blood vessels in the tumors. The number was counted in the whole area of each section, and mean number per $\mathrm{mm}^{2}$ was obtained. Each figure shows the average \pm SE. PEG-IFN: PEG-IFN- $\alpha 2 b$.

experiment used concentration levels close to those of Shang et al, and similar anti-tumor effects were obtained. However, the level of suppression in our study did not reach $50 \%$ of the control even though the concentrations were higher than those of Vyas et al. The reasons for these disparate findings are not clear, however, they may be related to the different cell density in the experiments, different measurement methods, and possible changes in cell characteristics due to cultures. Vyas et al (19) also reported that the anti-tumor effects of PEG-IFN- $\alpha 2 b$ and IFN- $\alpha 2 b$ were not markedly different as we demonstrated in the present study.

Some medical institutions administer the combination therapy of IFN- $\alpha$ and 5-FU in the treatment for advanced RCC. Sella et al (20) reported that the combination of IFN- $\alpha$ and chemotherapy (5-FU and mitomycin C) resulted in a significant clinical effect on RCC patients. Our results support the anti-tumor effects reported by Sella et al regarding the combination of IFN- $\alpha$ and chemotherapy. Moreover, in the present study, the combination of PEG-IFN- $\alpha 2 b$ and 5-FU exhibited enhanced anti-tumor effects in comparison to the combination of IFN- $\alpha 2 \mathrm{~b}$ and 5 -FU in vivo.

The induction of apoptosis is a mechanism of the antitumor effects of IFN- $\alpha 2 b$, and Vyas et al (19) reported a dosedependent increase in apoptotic cell number for PEG-IFN- $\alpha 2 b$ in cell cultures. Shang et al (18) found that apoptosis induction by IFN- $\alpha 2$ b was not significant even at a dose of 5,000 IU/ $\mathrm{ml}$. On the other hand, 5-FU induced apoptosis in a dosedependent manner, and 50 and $100 \mathrm{IU} / \mathrm{ml}$ of IFN- $\alpha 2 \mathrm{~b}$ was able to promote 5-FU-induced apoptosis in RCC cells. In our current study, the number of apoptotic cells in vitro increased proportionally to the dose of PEG-IFN- $\alpha 2 b$ and to the doses of PEG-IFN- $\alpha 2 b$ plus 5-FU in the combination treatment. The apoptotic cell number in the tumors also increased dosedependently in the IFN- $\alpha 2 b$ alone group and PEG-IFN- $\alpha 2 b$ alone group, and the number in each group further increased with the combination of 5-FU. This indicates that PEG-IFN- $\alpha 2 b$ and IFN- $\alpha 2 b$ induced apoptosis and the combination with 5 -FU induced apoptosis more extensively. Comparing the two combination treatments, i.e., PEG-IFN- $\alpha 2$ b plus 5-FU vs. IFN- $\alpha 2 b$ plus 5-FU, the estimated tumor volume was significantly smaller in the PEG-IFN- $\alpha 2$ b plus 5 -FU group, but the number of apoptotic cells did not differ markedly between the groups. Shang et al (18) revealed that IFN- $\alpha 2$ b caused cell cycle arrest at G1 in ACHN cells and at G2/M in Caki-1 cells in their flow cytometric analyses, and this suggests that cell cycle arrest could be the reason why there was no remarkable difference in the number of apoptotic cells in our results.

Anti-angiogenesis activity is a biological effect of IFN$\alpha 2 b$, and it has been shown that IFN- $\alpha 2 b$ inhibits angiogenesis by down-regulating angiogenesis factors. For example, Dinney et al (21) systematically administered IFN- $\alpha$ in a nude mouse model of bladder tumor and reported a decrease in in vivo blood vessel density in the tumors, which then resulted in the shrinkage of the tumor size. On the other hand, Kojiro et al (16) reported that there was no significant relation between the tumor shrinkage effects and angiogenesis factors or artery-like blood vessels when IFN- $\alpha$ and 5-FU were administered in combination to nude mice receiving transplantation of HCC cells. In our current study, the mRNA expression of VEGF and the number of artery-like blood vessels in the tumors were not suppressed in the PEG-IFN$\alpha 2 b$ alone group and the PEG-IFN- $\alpha 2 b$ plus 5-FU group, but the estimated tumor volume of the PEG-IFN- $\alpha 2 b$ plus 5-FU group was the most suppressed among the groups. The reason for these contrary findings is unclear. Angiogenesis plays an important role in the proliferation and metastasis of solid tumors such as renal cancer, therefore the relation between angiogenesis factors and anti-tumor effects should be investigated in future studies by using different IFN preparations and other RCC cell lines.

It has been reported that IFN directly suppresses tumor proliferation and at the same time augments the suppressive effects of 5-FU on tumor growth, including the induction of apoptosis $(15,22)$. In regards to the mechanism of this augmentation, several researchers reported that IFN- $\alpha$ acts on the metabolic pathway of 5-FU $(23,24)$. Low levels of TS and DPD and high levels of OPRT, TP, UP and TK render cancer cells sensitive to 5-FU. In our results, the enzymes related to 5-FU metabolism, except OPRT, slightly increased (not significantly) in comparison to the control. Therefore, the activity of 5-FU-related enzymes were not related to the antitumor effects shown in our PEG-IFN- $\alpha 2$ b plus 5-FU group.

IFN- $\alpha 2 b$ exerts its actions through a specific cell surface receptor, Type I IFN receptor, which consists of two subunits IFNAR-1 and IFNAR-2. IFNAR-2 is the binding subunit and is more important than IFNAR-1 for the expression of IFN$\alpha 2 \mathrm{~b}$ activity (25-27). Oie et al (17) examined the expression of type I IFN receptor mRNA in $6 \mathrm{HCC}$ cell lines treated with 5-FU. They showed that the expression of type I IFN receptor was markedly increased in the 3 cell lines whose proliferation was suppressed synergistically by the administration of 5-FU and IFN- $\alpha$ than in the other 3 cell lines whose proliferation was suppressed in an additive manner. In our current study, expression of IFNAR-1 and IFNAR-2 increased in the IFN- $\alpha 2 b$ alone and PEG-IFN- $\alpha 2 b$ alone groups, whereas the expression levels were markedly lower 
in the combination groups of IFN- $\alpha$ plus $5-\mathrm{FU}$ than in the IFN alone groups. These findings differ from those of Oie et al which could be the reason why the effects of our combination treatment were additive and not synergistic.

Our results confirmed that in the treatment of RCC, PEGIFN- $\alpha 2 b$ presents more potent anti-tumor effects than conventional non-pegylated IFN- $\alpha 2 b$, and the effects are augmented when 5-FU is used in combination. The most probable mechanism of this potent effect is apoptosis induction, and the target molecules that induce apoptosis will be determined in future studies. We expect that the addition of another agent to the combination of IFN- $\alpha 2 b$ and $5-F U$ would result in more potent anti-tumor effects in the treatment of RCC.

\section{Acknowledgements}

We thank Ms. Akemi Fujiyoshi for her assistance in our experiments. This study was supported by a Grant-in-Aid from the Ministry of Health, Labor and Welfare of Japan (no. 17200501) and by a Grant-in-Aid for Scientific Research (C) from the Ministry of Education, Science, Sports and Culture, Japan (no. 19590412).

\section{References}

1. Hartmann JT and Bokemeyer C: Chemotherapy for renal cell carcinoma. Anticancer Res 19: 1541-1543, 1999.

2. Atzpodien J, Lopez Hanninen E, Kirchner H, Bodenstein H, Pfreundschuh M, Rebmann U, Metzner B, Illiger HJ, Jakse G, Niesel T, et al: Multiinstitutional home-therapy trial of recombinant human interleukin-2 and interferon alfa- 2 in progressive metastatic renal cell carcinoma. J Clin Oncol 13: 497-501, 1995.

3. Hernberg M, Pyrhonen S and Muhonen T: Regimens with or without interferon-alpha as treatment for metastatic melanoma and renal cell carcinoma: an overview of randomized trials. J Immunother 22: 145-154, 1999.

4. Dutcher JP, Logan T, Gordon M, Sosman J, Weiss G, Margolin K, Plasse T, Mier J, Lotze M, Clark J and Atkins M: Phase II trial of interleukin 2, interferon alpha, and 5-fluorouracil in metastatic renal cell cancer: a cytokine working group study. Clin Cancer Res 6: 3442-3450, 2000.

5. Wadler S and Wiernik PH: Partial reversal of doxorubicin resistance by forskolin and 1,9-dideoxyforskolin in murine sarcoma S180 variants. Cancer Res 48: 539-543, 1988.

6. Baker DE: Pegylated interferon plus ribavirin for the treatment of chronic hepatitis C. Rev Gastroenterol Disord 3: 93-109, 2003.

7. Reddy KR, Wright TL, Pockros PJ, Shiffman M, Everson G, Reindollar R, Fried MW, Purdum PP III, Jensen D, Smith C, Lee WM, Boyer TD, Lin A, Pedder S and DePamphilis J: Efficacy and safety of pegylated (40-kd) interferon alpha-2a compared with interferon alpha-2a in noncirrhotic patients with chronic hepatitis C. Hepatology 33: 433-438, 2001.

8. Lindsay KL, Trepo C, Heintges T, Shiffman ML, Gordon SC, Hoefs JC, Schiff ER, Goodman ZD, Laughlin M, Yao R and Albrecht JK: A randomized, double-blind trial comparing pegylated interferon alfa- $2 b$ to interferon alfa- $2 b$ as initial treatment for chronic hepatitis C. Hepatology 34: 395-403, 2001.

9. Lee SD, Yu ML, Cheng PN, Lai MY, Chao YC, Hwang SJ, Chang WY, Chang TT, Hsieh TY, Liu CJ and Chen DS: Comparison of a 6-month course peginterferon alpha-2b plus ribavirin and interferon alpha- $2 \mathrm{~b}$ plus ribavirin in treating Chinese patients with chronic hepatitis C in Taiwan. J Viral Hepat 12: 283-291, 2005.

10. Bruno S, Camma C, Di Marco V, Rumi M, Vinci M, Camozzi M, Rebucci C, Di Bona D, Colombo M, Craxi A, Mondelli MU and Pinzello G: Peginterferon alfa-2b plus ribavirin for naive patients with genotype 1 chronic hepatitis C: a randomized controlled trial. J Hepatol 41: 474-481, 2004.
11. Yano H, Yanai Y, Momosaki S, Ogasawara S, Akiba J, Kojiro S, Moriya F, Fukahori S, Kurimoto $M$ and Kojiro M: Growth inhibitory effects of interferon-alpha subtypes vary according to human liver cancer cell lines. J Gastroenterol Hepatol 21: 1720-1725, 2006.

12. Motzer RJ, Rakhit A, Ginsberg M, Rittweger K, Vuky J, Yu R, Fettner S and Hooftman L: Phase I trial of 40-kd branched pegylated interferon alfa-2a for patients with advanced renal cell carcinoma. J Clin Oncol 19: 1312-1319, 2001.

13. Yano H, Maruiwa M, Sugihara S, Kojiro M, Noda S and Eto K: Establishment and characterization of a new human renal cell carcinoma cell line (KRC/Y). In Vitro Cell Dev Biol 24: 9-16, 1988.

14. Hisaka T, Yano H, Ogasawara S, Momosaki S, Nishida N, Takemoto Y, Kojiro S, Katafuchi Y and Kojiro M: InterferonalphaCon1 suppresses proliferation of liver cancer cell lines in vitro and in vivo. J Hepatol 41: 782-789, 2004

15. Chou T-C and Talalay P: Analysis of combined drug effects: a new look at a very old problem. Trends Pharmacol Sci 4: 450-454, 1983.

16. Kojiro S, Yano H, Ogasawara S, Momosaki S, Takemoto Y, Nishida $\mathrm{N}$ and Kojiro M: Antiproliferative effects of 5fluorouracil and interferon-alpha in combination on a hepatocellular carcinoma cell line in vitro and in vivo. J Gastroenterol Hepatol 21: 129-137, 2006.

17. Oie S, Ono M, Yano H, Maruyama Y, Terada T, Yamada Y, Ueno T, Kojiro M, Hirano K and Kuwano M: The up-regulation of type I interferon receptor gene plays a key role in hepatocellular carcinoma cells in the synergistic antiproliferative effect by 5 -fluorouracil and interferon- $\alpha$. Int J Oncol 29: 1469-1478, 2006.

18. Shang D, Ito N, Watanabe J, Awakura Y, Nishiyama H, Kamoto T and Ogawa O: Synergy of interferon-alpha and 5-fluorouracil in human renal cell carcinoma requires p53 activity. Eur Urol 52: 1131-1139, 2007

19. Vyas K, Brassard DL, DeLorenzo MM, Sun Y, Grace MJ, Borden EC and Leaman DW: Biologic activity of polyethylene glycol 12000-interferon-alpha2b compared with interferonalpha2b: gene modulatory and antigrowth effects in tumor cells. J Immunother 26: 202-211, 2003.

20. Sella A, Logothetis CJ, Fitz K, Dexeus FH, Amato R, Kilbourn R and Wallace S: Phase II study of interferon-alpha and chemotherapy (5-fluorouracil and mitomycin C) in metastatic renal cell cancer. J Urol 147: 573-577, 1992.

21. Dinney CP, Bielenberg DR, Perrotte P, Reich R, Eve BY, Bucana CD and Fidler IJ: Inhibition of basic fibroblast growth factor expression, angiogenesis, and growth of human bladder carcinoma in mice by systemic interferon-alpha administration. Cancer Res 58: 808-814, 1998.

22. Oka Y, Naomoto Y, Yasuoka Y, Hatano H, Haisa M, Tanaka N and Orita K: Apoptosis in cultured human colon cancer cells induced by combined treatments with 5-fluorouracil, tumor necrosis factor-alpha and interferon-alpha. Jpn J Clin Oncol 27: 231-235, 1997.

23. Kase S, Kubota T, Watanabe M, Teramoto T, Kitajima $M$ and Hoffman RM: Recombinant human interferon alpha-2a increases 5-fluorouracil efficacy by elevating fluorouridine concentration in tumor tissue. Anticancer Res 14: 1155-1159, 1994.

24. Schwartz EL, Hoffman M, O'Connor CJ and Wadler S: Stimulation of 5-fluorouracil metabolic activation by interferonalpha in human colon carcinoma cells. Biochem Biophys Res Commun 182: 1232-1239, 1992.

25. Pestka S, Langer JA, Zoon KC and Samuel CE: Interferons and their actions. Annu Rev Biochem 56: 727-777, 1987.

26. Lutfalla G, Holland SJ, Cinato E, Monneron D, Reboul J, Rogers NC, Smith JM, Stark GR, Gardiner K, Mogensen KE, et al: Mutant U5A cells are complemented by an interferonalpha beta receptor subunit generated by alternative processing of a new member of a cytokine receptor gene cluster. EMBO J 14: 5100-5108, 1995.

27. Domanski P, Witte M, Kellum M, Rubinstein M, Hackett R, Pitha $\mathrm{P}$ and Colamonici OR: Cloning and expression of a long form of the beta subunit of the interferon alpha beta receptor that is required for signaling. J Biol Chem 270: 21606-21611, 1995. 